THURSDAY, FEBRUARY 26, 1920.

\section{METEOROLOGY AND THE STATE.}

$\mathrm{D}$ URING the war, meteorology, like many other branches of science, was utilised to an unexpected extent, and its importance has thereby gained recognition in far wider circles than might otherwise have been the case. The rapid development of aviation has contributed to this, for accurate forecasts and a knowledge of the conditions prevailing in the upper air are of the greatest importance to the airman, and the subject now forms a part of his course of instruction.

With the cessation of hostilities, the Meteorological Office has had to consider the reconstruction which would be necessary in its organisation to meet the larger demands made upon it, and to maintain the expansion and development of the scientific side of the subject which such increased activity demanded. In other countries the meteorological service has always been part of one of the Departments of State, but in this country its status has varied from time to time. The Meteorological Office began in 1854 as a Department of the Board of Trade for the purpose of collecting information about the meteorology of the sea, to which was added later the study of forecasting. Later, it was placed under a committee appointed by the Royal Society, which administered the funds furnished by an annual grant-in-aid. Since 1905 the Office has been under the management of a Committee appointed by the Treasury, and consisting of representatives of the Admiralty, Board of Trade, Board of Agriculture and Fisheries, and the Royal Society. Thus the Meteorological Office has for many years been a service mainly supported by State funds, but not attached to any Department, its policy being determined by the Committee responsible for its administration.

Under these conditions much valuable scientific work has been done, and, whatever the advantages of such an independent position may have been, the greatly increased utilisation of meteorological information by various Departments of State has recently brought the status of the Meteorological Office under consideration.

In the report of the Meteorological Committee for the year ending March 3I, 1919, a proposal of the Air Ministry made in the spring of $19 \mathrm{I} 8$ to take over the Office, on account of the importance of meteorology to aviation and of the use of aviation to meteorology, is presented; but no definite action was taken at the time. Later in the year a Committee of the Cabinet was in favour of transferNO. 2626, VOL. IO4] ring the meteorological service to the Department of Scientific and Industrial Research, with a view to the co-ordination of the various meteorological services then existing. Such a scheme appeared to afford a satisfactory means of meeting the requirements of the Departments, and also of maintaining the scientific research essential to advance in meteorology.

Since then it has been announced by the UnderSecretary of State for Air that the Cabinet has decided that the Meteorological Office should be attached to the Air Ministry, and the amalgamation of the staff of the Meteorological Office with that of the Meteorological Service of the Air Ministry is understood to be in course of execution. W'e may therefore conclude that the importance of the State Meteorological Service to the modern needs of the fighting Services, as well as to the other Departments of State, is such as to render its closer connection with them desirable, and apparently the special needs of the Air Ministry and its exceptional facilities for obtaining information from the upper regions of the atmosphere have led to its selection as the Ministry to which the Meteorological Office should be attached.

Such recognition of the importance of meteorological science, and the co-ordination of different services dealing with the subject, are to be welcomed, but men of science will wish to see the freedom for investigation and research which has been a special feature of the Office under its former committees of management fully maintained under the new conditions arising from its reincorporation in a State Department. Some misgivings on this point seem to exist, for the council of the Royal Meteorological Society, in a resolution published elsewhere in this issue, while recognising the advantages which the Meteorological Office may gain from a closer association with the Air Ministry, suggests that there may be a tendency for certain branches of meteorology to be relegated to a subordinate position of importance if the management of the Service rests with a single Department having special interests of its own.

Here we meet the difficulty of reconciling the advantages gained from the support and resources of an influential Ministry with such restrictions as are inseparable from the administration of a large Service. The special interests and requirements of a controlling Department will naturally appeal more strongly to its administrators, and proposals for expenditure on schemes will gain more sympathy and support than others with which they 
are less familiar. Such considerations probably influenced the Meteorological Committee in concurring in the proposal for transference to the Department of Scientific and Industrial Research.

But, since the incorporation of the Meteorological Office in a State Department is necessary, as seems to be generally agreed, the important matter is how advance in all branches of the subject may be assured. Besides forecasts of the weather and information concerning conditions in the upper air which especially affect the Air Ministry, there are the needs of the Navy, the mercantile marine, and the shipping community in general; the interests of farmers, foresters, and fruit-growers; the requirements of water engineers, river conservancies, and many other branches of the community. The War Office has special demands of its own in connection with gunnery, sound-ranging, etc., and there are many questions coming within the scope of the Ministry of Health and other Government Departments which utilise meteorological information. For all these lines of work, scientific investigation must be carried on continuously in order to obtain fuller knowledge of the atmospheric processes which can be utilised to the advantage of the various interests which have been mentioned. To this end observatories are maintained for investigation apart from their utility as reporting stations, and it is of the utmost importance that such scientific research should be continued and afforded full freedom of action.

With its transfer to the Air Ministry, the Meteorological Office has gained a large addition to its staff, and with its extended network of reporting stations its budgetary provision in the coming financial year will doubtless be greatly increased. The State Service is still almost the only one offering a career to a man who is attracted to the subject of meteorology, and if those of the best ability are to be obtained, it is essential that scientific research in it should be encouraged in which their powers may be utilised. No announcement has so far been made of the constitution of the Committee which continues the work of the Meteorological Committee, or of its powers and responsibilities, but it is to be hoped that science will be strongly represented on such a Committee which can advise the Air Ministry on the best policy to be pursued for the advancement of meteorological science, and will be empowered to direct the execution of such policy. By this means the Ministry will be assured that research will be carried on most efficiently and to the advantage of all branches of the subject. NO. 2626, VOL. IO4]
THE BIRTH OF OCEANOGRAPHY. Accounts Rendered of Work Done and Things Seen. By J. Y. Buchanan. Pp. 1vii $+435+3$ plates. (Cambridge: At the University Press, I9I9.) Price 2Is. net.

MR. J. Y. BUCHANAN has passed the I allotted span of years, but we who are no longer young cannot call him old. Yet he was hard at work in a generation which has all but passed away, and his recollection reaches back to things which are but a tradition to the most of us. He is the last of that happy band who set sail from Portsmouth in the Challenger under Wyville Thomson just seven-and-forty years ago; he was born in another world than ours, when (as he tells us) the only railways on the Continent ran, as kings' playthings, from Paris to Versailles, from Berlin to Potsdam, from Hanover to Herrenshausen. Now in this volume, as in one before, he has "rendered his accounts" (but only partially) of the abundant work he has aone and the countless things he has seen. The book contains essays both great and small, from letters to NATURE to addresses delivered to universities and learned societies, and the things of which these papers treat are both big and little, for Mr. Buchanan has kept a sharp look-out, conning everything-from the rats in a Bordighera garden (which left the oranges alone, ate the rind of lemons and left the fruit, ate the fruit of mandarins and left the rind) to the great panoramas of earth and sea which for so many years have passed before him.

Most of the papers deal (as we should expect) with matters oceanographical, such as the temperature of the sea, its colour, its saltness, or the manganese and other nodules lying in its bed. The treatment is in great measure new, or was so when the papers were written; but the themes are old - and are made all the more attractive thereby. One is reminded of Robert Boyle's "Observationes de salsedine maris," or, again, of the "Histoire Physique de la Mer"based upon so little, because it was all there was - of that exquisite writer and gallant soldier of fortune, Louis Ferdinand, Comte de Marsilli. Even one or two names like these (and we do not forget Captain Maury, another great captain and soldier of fortune) make us hesitate a little to accept Mr. Buchanan's account of "The Birthday of Oceanography." And yet perhaps he is not very far wrong to persuade, us that that science was born, a little to the westward of Teneriffe, on February I5, 1873. For this was the day when the Challenger made her first oceanic sounding; and, immediately after, the dredge came up full of new and strange things, 